\title{
PENGARUH PENGGUNAAN MEDIA PEMBELAJARAN DAN KREATIVITAS TERHADAP KEMAMPUAN MENULIS HURUF PADA PENDIDIKAN ANAK USIA DINI (PAUD)
}

\author{
Flora Marantika Ginting ${ }^{1}$, R. Mursid ${ }^{2}$, Mukhtar $^{3}$ \\ ${ }^{1}$ BP-Pendidikan Anak Usia Dini (PAUD) dan Dikmas Sumatera Utara \\ ${ }^{2,3}$ Pascasarjana Universitas Negeri Medan \\ floraginting610@yahoo.com ${ }^{l}$
}

\begin{abstract}
Abstrak: Penelitian ini bertujuan untuk mengetahui: (1) pengaruh media pembelajaran video dan kartu huruf terhadap kemampuan menulis huruf anak usia dini di PAUD Kenanga Raya Medan; (2) pengaruh kreativitas tinggi dan kreativitas rendah terhadap kemampuan menulis huruf anak usia dini di PAUD Kenanga Raya Medan; dan (3) pengaruh interaksi antara media pembelajaran dan kreativitas terhadap kemampuan menulis huruf anak usia dini di PAUD Kenanga Raya Medan. Penelitian ini bersifat eksperimen semu (quasi experiment). Metode penelitian dengan menggunakan kuasi eksperimen dengan desain faktorial $2 x$ 2. Berdasarkan hasil penelitian diperoleh: (1) Kemampuan menulis huruf anak yang mengikuti pembelajaran dengan menggunakan media pembelajaran video lebih tinggi daripada anak yang mengikuti pembelajaran dengan menggunakan media pembelajaran kartu huruf dimana harga Fhitung $=378.14$, Ftabel $=4.12$ pada taraf signifikansi 0,05; (2) Kemampuan menulis huruf anak yang memiliki kreativitas tinggi lebih tinggi daripada anak yang memiliki kreativitas rendah berdasarkan media pembelajaran, harga Fhitung $=44.5, \quad$ Ftabel $=4.12$ pada taraf signifikansi 0,05 dan (3) Terdapat pengaruh interaksi antara belajar dengan menggunakan media pembelajaran dan kreativitas terhadap Kemampuan menulis huruf dengan Fhitung $=90.4$, Ftabel $=4.12$ pada taraf signifikansi 0,05. Hasil penelitian yang diperoleh diharapkan memberikan informasi bagi guru dan sekolah untuk menggunakan media pembelajaran video dalam meningkatkan kemampuan menulis huruf anak PAUD. Selain itu perlu ditingkatkan kreativitas anak dalam pembelajaran di kelas.
\end{abstract}

Kata Kunci : media pembelajaran, kreativitas, kemampuan menulis huruf

\begin{abstract}
This study aims to determine: (1) the influence of video learning media and letter cards on the ability to write early childhood letters in Kenanga Raya PAUD Medan; (2) the effect of high creativity and low creativity on the ability to write early childhood letters in Kenanga Raya PAUD Medan; and (3) the effect of interaction between learning media and creativity on the ability to write early childhood letters in Kenanga Raya PAUD Medan. This research is quasi-experimental. The research method using quasiexperimental with $2 \times 2$ factorial design. Based on the results of the study obtained: (1) The ability to write letters of children who follow learning using video learning media is higher than children who follow learning by using learning media letter cards where the price of Fcount $=378.14$, Ftable $=4.12$ at the significance level of 0.05; (2) The ability to write letters of children who have high creativity is higher than children who have low creativity based on learning media, the price of Fcount $=44.5$, Ftable $=4.12$ at a significance level of 0.05 and (3) There is an influence of interaction between learning by using learning media and creativity to the ability to write letters with Fcount $=90.4$, Ftable $=4.12$ at a significance level of 0.05. The results obtained are expected to provide information for teachers and schools to use video learning media in improving the ability to write PAUD children's letters. Besides that, it is necessary to increase children's creativity in learning in class.
\end{abstract}

Keywords: learning media, creativity, letter writing ability

\section{PENDAHULUAN}

Anak TK yang berusia 4 - 5 atau 6 tahun memiliki energi yang tinggi untuk melakukan berbagai kegiatan yang diperlukan dalam meningkatkan berbagai kegiatan yang diperlukan dalam meningkatkan keterampilan fisik, baik yang berkaitan dengan peningkatan keterampilan motorik kasar maupun motorik halus. Kegiatan fisik dan pelepasan energi dalam jumlah besar merupakan karakteristik aktivitas anak pada masa ini. Hal itu disebabkan oleh energi yang dimiliki anak dalam jumlah yang besar tersebut memerlukan penyaluran melalui berbagai aktivitas fisik, baik kegiatan fisik yang berkaitan dengan gerakan motorik kasar maupun gerakan motorik halus.

Menurut Jamaris (2006:8) pada usia 5 atau 6 tahun, koordinasi gerakan motorik halus 
berkembang dengan pesat. Pada masa ini, anak telah mampu mengkoordinasikan gerakan motorik, seperti mengkoordinasikan gerakan mata dengan gerakan tangan, lengan, dan tubuh secara bersamaan, antara lain atau dapat dilihat pada waktu anak menulis atau menggambar.

Sudono (2000:27) menyatakan bahwa praktek pendidikan anak saat ini mengandalkan kertas dan pensil, sehingga alokasi waktu terserap untuk kegiatan tersebut yang berakibat evaluasi terhadap kemajuan anak hanya ditekankan pada kemampuan baca dan tulis saja.

Kemampuan penggunan berbagai media sangatlah penting dikuasai oleh guru anak usia dini dalam kegiatan mengajar. Guru perlu secara kontinu menggunakan media pembelajaran dan apabila guru menggunakan media dalam melaksanakan kegiatan pembelajarannya, anak jadi tertarik, merasa senang, termotivasi untuk belajar dan menumbuhkan rasa ingin tahu anak. Di luar negeri seperti negara Australia, Inggris dan lain-lain telah dikembangkan berbagai media untuk pembelajaran keterampilan menulis anak, baik visual maupun audio visual. Media yang terkenal dan efektif untuk keterampilan menulis adalah program dari youtube. Banyak pilihan dari isi program ini dalam mengenalkan huruf dengan dengan metode bernyanyi, permainan, percakapan, dan animasi dimana anak yang secara rutin menonton program ini, memiliki kemampuan mengenal dan menulis huruf dengan baik.

\section{Hakikat Kemampuan Menulis Huruf}

Menurut Kasanah \& Tuminto (2007:423) kemampuan adalah kesanggupan, kecakapan atau kekuatan. Kunandar (2007:51) mengartikan kemampuan adalah merupakan perilaku yang rasional untuk mencapai tujuan yang dipersyaratkan sesuai dengan kondisi yang diharapkan. Kemampuan merupakan salah satu hal yang harus dimiliki dalam jenjang apapun karena kemampuan memiliki kepentingan tersendiri dan sangat penting untuk dimiliki oleh seseorang. Di sisi lain kemampuan dipahami sebagai seperangkat tindakan intelegen penuh tanggung jawab yang harus dimiliki seseorang sebagai syarat untuk dianggap mampu melaksanakan tugas-tugas dalam bidang pekerjaan tertentu. Sifat intelegen harus ditunjukkan sebagai kemahiran, ketepatan dan keberhasilan bertindak, sedangkan sifat tanggung jawab harus ditunjukkan sebagai kebenaran tindakan baik dipandang dari sudut ilmu pengetahuan, teknologi maupun etika (Majid, 2006:5). Berdasarkan pengertian tersebut, dapat dikatakan bahwa kemampuan adalah kesanggupan, kecakapan atau kekuatan untuk menguasai atau mengerjakan sesuatu. Pada program PAUD, kemampuan yang diharapkan adalah kemampuan motorik halus anak yaitu kemampuan anak dalam menulis huruf a sampai $z$.

Pengembangan kemampuan berdasarkan Program Kegiatan Belajar Taman Kanak-kanak (PKBTK) bertujuan untuk mengembangkan keterampilan motorik halus anak pada olah tangan. Menurut Hurlock (dalam Yusuf, 2000:104) bahwa "keterampilan kemampuan motorik halus atau keterampilan manipulasi meliputi menulis, menggambar, memotong, melempar dan menangkap bola serta memainkan alat-alat permainan."

Sujiono (2010:13) mengungkapkan bahwa: "kemampuan motorik halus adalah keterampilan yang gerakannya hanya melibatkan bagian-bagian tubuh tertentu saja dan dilakukan oleh otot-otot kecil, seperti keterampilan menggunakan jari jemari tangan dan gerakan pergelangan tangan yang tepat". Defenisi di atas mengungkapkan bahwa keterampilan motorik halus hanya melibatkan bagian tubuh tertentu. Keterampilan motorik halus menggunakan jari jemari tangan dan otototot kecil. Keterampilan ini membutuhkan kelenturan tangan dan koordinasi antara mata dan tangan.

$$
\text { Menurut Suyadi (2010:69) }
$$

"kemampuan gerak motorik halus adalah meningkatnya pengoordinasian gerak tubuh yang melibatkan otot dan syaraf yang jauh lebih kecil atau detail". Kelompok otot dan syaraf inilah yang nantinya mampu mengembangkan gerak motorik halus seperti meremas kertas, menyobek, menggambar, menulis dan lain sebagainya. Lain pula, menurut Moeslichatoen (2004:5) motorik halus merupakan kegiatan yang menggunakan otot-otot halus untuk melakukan pekerjaan menggambar, melipat, menggunting, membentuk dan sebagainya. Menurut pengertian di atas, motorik halus adalah kegiatan yang memanfaatkan otot-otot pada jari tangan. Keterampilan ini menggunakan otot-otot halus yang membutuhkan kecermatan seseorang terutama untuk kegiatan menulis. Pendapat di atas mengungkapkan bahwa kemampuan motorik halus memerlukan kecermatan antara mata dan 
tangan, dan perlu dilakukan secara berulangulang.

Kemampuan motorik halus anak akan berkembang secara optimal apabila adanya stimulus yang diberikan. Benyamin dalam Suyadi (2010:73) menyatakan bahwa tentang penguasaan psikomotorik ditunjukkan oleh gerakan yang kaku sampai pada gerakan yang lancer dan luwes.

Perkembangan berbahasa anak meliputi perkembangan berbicara, menulis, membaca, dan menyimak. Perkembangan bahasa anak yang dibahas pada kemampuan ini adalah perkembangan bahasa anak yaitu perkembangan menulis. Menurut Mulyati, dkk (2011:13) menulis adalah keterampilan produktif dengan menggunakan tulisan. Menulis dapat dikatakan suatu keterampilan berbahasa yang paling rumit diantara jenis-jenis keterampilan berbahasa lainnya. Ini karena menulis bukan hanya sekedar menyalin katakata dan kalimat; melainkan juga mengembangkan dan menuangkan pikiran dalam suatu struktur tulisan yang teratur. Hal senada disampaikan oleh Nurbiana Dhieni, dkk (2011: 3.10) mengatakan bahwa menulis merupakan salah satu media untuk berkomunikasi, dimana anak dapat menyampaikan makna, ide, pikiran dan perasaannya melalui untaian kata-kata bermakna. Menurut Poerwadarminta (1982) yang ditulis kembali oleh Nurbiana Dhieni, dkk (2011: 3.10) menulis memiliki batasan sebagai berikut: (1) membuat huruf, angka, dan lainnya dengan pena, kapur dan sebagainya; (2) mengekspresikan pikiran atau perasaan seperti mengarang, membuat surat, dan lainnya dengan tulisan. Senada dengan pernyataan tersebut Badudu (1982) dalam Nurbiana Dhieni, dkk (2011:3.10) mengemukakan bahwa menulis adalah menggunakan pena, potlot, ballpoint di atas kertas, kain, ataupun papan yang menghasilkan huruf, kata, maupun kalimat. Dengan demikian menulis bukanlah sekedar membuat huruf-huruf ataupun angka pada selembar kertas dengan menggunakan berbagai alternatif media, melainkan merupakan upaya untuk mengekspresikan perasaan dan pikiran yang ada pada diri individu. pada hakikatnya adalah menuangkan gagasan pendapat, perasaan keinginan serta informasi kedalam tulisan dan kemudian mengirimkannya kepada orang lain. Hal berbeda disampaikan oleh Tarigan (1991:20) pengertian menulis adalah menurunkan dan melukiskan lambang-lambang grafis yang menggambarkan suatu bahasa yang dipahami oleh seseorang sehingga orang lain dapat membaca lambang-lambang grafik tersebut. Kalau memahami bahasa dan grafis itu gambar atau lukisan mungkin dapat menyampaikan makna, tetapi tidak menggambarkan kesatuan bahasa. Menulis merupakan presentasi bagian dari ekspresi bahasa. Hal ini menjadi perbedaan utama antara menulis dan melukis. Dari uraian diatas dapat disimpulkan bahwa menulis adalah keseluruhan rangkaian kegiatan seseorang mengungkapkan gagasan melalui alat tulis kepada pembaca untuk dipahami secara tepat.

Ehri \& McCormick (1998) dalam Carol Seefeldt (2008: 330) mengatakan bahwa belajar abjad adalah komponen hakiki dari perkembangan baca tulis. Meskipun beberapa anak bisa membaca beberapa kata dan mengenal huruf cetak lingkungan sebelum mereka mengetahui abjad, anak-anak perlu mengetahui abjad untuk akhirnya menjadi pembaca dan penulis yang mandiri dan lancar. Anak usia dini mengahadapi tantangan saat mereka pertama kali mulai mempelajari huruf abjad. Penelitian menunjukkan bahwa anakanak memulai dengan mencirikan bentuk berbeda dari huruf-huruf. Bentuk-bentuk yang berbeda dari abjad kita adalah huruf-huruf seperti sebuah garis lurus atau lengkung (seperti "I" atau "C") atau apakah lengkung-lengkung itu terbuka atau tertutup (seperti dalam " $\mathrm{C}$ " atau "O”. (Gibson, 1969 dalam Carol Seefeldt, 2008:331).

Adapun tahap perkembangan kemampuan menulis menurut Jamaris (2006:55-56) adalah sebagai berikut :

1) Tahap Mencoret, pada tahap ini, anak mulai membuat tanda-tanda dengan menggunakan alat tulisan. Mereka mulai belajar tentang bahasa tulisan dan bagaimana mengerjakan tulisan tersebut.

2) Tahap Pengulangan Secara Linear, pada tahap ini, anak sudah dapat menelusuri atau menjiplak bentuk tulisan yang horizontal. Dalam masa ini anak berpikir bahwa suatu kata merujuk pada sesuatu yang besar dan mempunyai tali yang panjang.

3) Tahap Menulis Secara Acak, pada masa ini, anak sudah dapat mempelajari berbagai bentuk yang dapat diterima sebagai suatu tulisan, dan menggunakannya sebagai kata atau kalimat. Anak sudah dapat mengubah tulisan menjadi kata yang mengandung pesan. 
4) Tahap Menulis Tulisan Nama, pada tahap ini, anak sudah mulai menyusun hubungan tulisan dan bunyi. Tahap ini digambarkan sebagai menulis tulisan nama dan bunyi secara bersamaan. Seperti "kamu". Maka pada fase ini berbagai kata yang mengandung akhiran $u$ mulai dihadirkan dengan kata dan tulisan.

5) Tahap Menulis Kalimat Pendek, setelah anak dapat menulis namanya, maka kegiatan selanjutnya ialah mengajak anak untuk menulis kalimat pendek. Kalimat tersebut terdiri dari subjek dan predikat, seperti "buku ani".

Menurut Brewer dalam Nurbiana

Dhieni, dkk (2011:3.10-3.11), ada 4 tahapan dalam kemampuan menulis sebagai berikut:

1) Scribble Stage, yaitu tahap mencoret atau membuat goresan. Pada tahap ini anak mulai membuat tanda-tanda dengan menggunakan alat tulis. Pada tahap ini mereka mulai belajar tentang bahasa tulis dan cara mengerjakan tulisan tersebut.

2) Linear Repetitive Stage, yaitu tahap pengulangan linear. Pada tahap ini anak menelusuri bentuk tulisan yang horizontal.

3) Random Letter Stage, yaitu tahap menulis random. Pada tahap ini anak belajar tentang berbagai bentuk yang merupakan suatu tulisan dan mengulang berbagai kata ataupun kalimat.

4) Letter Name Writing or Phonetic Writing, yaitu tahap menulis nama. Pada tahap ini anak mulai menyusun dan menghubungkan antara tulisan dan bunyinya. Anak mulai menulis nama dan bunyi secara bersamaan.

\section{Hakikat Media Pembelajaran}

Menurut Gerald \& Ely (1971) dalam Arsyad (2014:3) mengatakan bahwa media apabila dipahami secara garis besar adalah manusia, materi, atau kejadian yang membangun kondisi yang membuat siswa mampu memperoleh pengetahuan, keterampilan, atau sikap. Dalam pengertian ini, guru, buku teks, dan lingkungan sekolah merupakan media. Secara lebih khusus, pengertian media dalam proses belajar mengajar cenderung diartikan sebagai alat-alat grafis, fotografis atau elektronis untuk menangkap, memproses, dan menyusun kembali informasi visual atau verbal.

Menurut AECT (Hasnida: 2015:33) memberi batasan tentang media sebagai segala bentuk dan saluran yang digunakan untuk menyampaikan pesan atau informasi. Sementara itu, Gagne dalam Sadiman, dkk (2007:6-7) menyatakan bahwa media adalah berbagai jenis komponen dalam lingkungan siswa yang dapat merangsangnya untuk belajar. Apapun batasan yang diberikan, ada persamaan di antara batasan tersebut yaitu bahwa media adalah segala sesuatu yang dapat digunakan untuk menyalurkan pesan dari pengirim ke penerima sehingga dapat merangsang pikiran, perasaan, perhatian, dan minat serta perhatian siswa sedemikian rupa sehingga proses belajar terjadi. Lebih lanjut, menurut Sadiman, dkk, (2007:28) jenis media yang lazim dipakai dalam kegiatan belajar mengajar yaitu (1) media grafis, seperti gambar/foto, sketsa, diagram, bagan/chart, grafik, kartun, poster, peta, papan flanel, transparansi buletin, (2) media audio seperti radio, alat perekam, pita magnetic, (3) media proyeksi diam, seperti film bingkai, film rangkai, media transparansi, proyeksi tak tembus pandang, mikrofis, film, film gelang, televisi, video dan permainan dan simulasi. Sementara menurut Smaldino, dkk (2011:7) media merupakan sarana komunikasi yang merujuk pada apa saja yang membawa informasi antara sebuah sumber dan sebuah penerima.

Saran yang dapat mendorong penggunaan media pembelajaran adalah: Menurut Schramm (1977) mengatakan media dapat dimanfaatkan untuk keperluan pembelajaran. Sementara itu, Briggs (1977) mengemukakan media pembelajaran sebagai sarana fisik untuk menyampaikan isi/materi pembelajaran seperti: buku, film, video dan sebagainya. Sedangkan, National Education Associaton (1969) menyatakan bahwa media pembelajaran sebagai sarana komunikasi dalam bentuk cetak maupun pandang-dengar, termasuk teknologi perangkat keras. Dari ketiga pendapat di atas disimpulkan bahwa penggunaan media pembelajaran dapat menyalurkan pesan, merangsang pikiran, perasaan, dan kemauan peserta didik sehingga dapat mendorong terciptanya proses belajar pada diri peserta didik.

Kegiatan belajar anak didik pada hakikatnya adalah pemrolehan pengalaman belajar dalam usaha memanfaatkan media sebagai alat bantu pembelajaran, seorang ahli pendidikan Edgar Dale seperti yang dikutip oleh Sadiman (2007:8) membuat klasifikasi pengalaman belajar menurut tingkat dari yang paling konkret ke paling abstrak. Klasifikasi 
tersebut dikenal dengan nama kerucut pengalaman atau Cone of Experience. Kerucut pengalaman belajar yang akan diperoleh anak, mulai dari pengalaman belajar langsung/konkret dan pengalaman belajar yang bersifat tidak langsung/abstrak.

Arsyad (2014:10) mengemukakan bahwa media pembelajaran adalah segala sesuatu yang dapat digunakan untuk menyampaikan pesan atau informasi dalam proses belajar mengajar sehingga dapat merangsang perhatian dan minat siswa dalam belajar. Sementara itu, Gagne dan Briggs (1975) dalam Hasnida (2015:34), secara implisit mengatakan bahwa media pembelajaran meliputi alat yang secara fisik digunakan untuk menyampaikan isi materi pengajaran yang terdiri dari buku, tape recorder, kaset, video camera, video recorder, film slide (gambar bingkai), foto, gambar, grafik, televisi, dan komputer. Dengan kata lain, media adalah komponen sumber belajar atau wahana fisik yang mengandung materi instruksional di lingkungan siswa yang dapat merangsang siswa untuk belajar.

Secara umum dalam menggunakan media pengajaran, hendaknya guru memperhatikan sejumlah prinsip-prinsip tertentu agar penggunaan media dapat mencapai hasil yang baik. Agar media pengajaran yang dipilih itu tepat, disamping memenuhi prinsipprinsip pemilihan, juga terdapat beberapa faktor dan kriteria yang perlu diperhatikan menurut Djamarah (2006:128-130) adalah sebagai berikut :

a) Objektivitas. Metode dipilih bukan atas kesenangan atau kebutuhan guru, melainkan keperluan sistem belajar. Karena itu perlu masukan dari siswa.

b) Program Pengajaran. Program pengajaran yang akan disampaikan kepada anak didik harus sesuai dengan kurikulum yang berlaku, baik menyangkut isi, strukturnya, maupun kedalamannya.

c) Sasaran Program. Media yang digunakan harus dilihat kesesuaiananya dengan tingkat perkembangan anak didik, baik dari segi bahasa, sombol-simbol yang digunakan, cara dan kecepatan penyajiannya ataupun waktu penggunaannya.

d) Situasi dan kondisi. Yakni situasi dan kondisi sekolah atau tempat dan ruangan yang akan dipergunakan, baik ukuran, perlengkapan, maupun ventilasinya, situasi serta kondisi anak didik yang akan mengikuti pelajaran baik jumlah, motivasi, dan kegairahannya.

e) Kualitas teknik. Dari segi teknik, media pengajaran yang akan digunakan perlu diperhatikan, apakah sudah memenuhi syarat.

f) Keefektifan dan efisiensi penggunaan. Keefektifan berkenaan dengan hasil yang dicapai, sedangkan efisiensi berkenaan dengan proses pencapaian hasil tersebut.

Menurut Hasnida (2015:49-50) ada beberapa hal yang harus diperhatikan dalam pemanfaatan media pembelajaran di TK/PAUD antaranya sebagai berikut:

1) Penggunaan media pembelajaran bukan merupakan fungsi tambahan, melainkan memiliki fungsi tersendiri sebagai sarana bantu untuk mewujudkan situasi pembelajaran yang lebih efektif.

2) Media pembelajaran merupakan bagian integral dari keseluruhan proses pembelajaran. Hal itu mengandung pengertian bahwa media pembelajaran sebagai salah satu komponen yang tidak berdiri sendiri, tetapi saling berhubungan dengan komponen lainnya dalam rangka menciptakan situasi belajar yang diharapkan.

3) Media pembelajaran dalam penggunaannya harus relevan dengan tujuan dan isi pembelajaran, hal ini mengandung makna bahwa penggunaan media dalam pembelajaran harus mengacu kepada tujuan atau kemampuan yang akan dikuasai anak dan bahan ajar.

4) Media pembelajaran berfungsi untuk mempercepat proses belajar. Dengan media pembelajaran, anak dapat menangkap tujuan dan bahan ajar lebih mudah dan lebih cerdas.

5) Media pembelajaran berfungsi untuk meningkatkan kualitas proses pembelajaran. Pada umumnya, hasil belajar anak dengan menggunakan media pembelajaran lebih tahan lama mengendap di dalam pikirannya, sehingga kualitas pembelajaran memiliki nilai yang tinggi.

6) Media pembelajaran meletakkan dasar-dasar yang konkret untuk berpikir, oleh karena itu dapat mengurangi verbalisme.

\section{Media Pembelajaran Video}

Menurut Hasnida (2015: 68) media audio visual merupakan kombinasi dari media 
audio dan media visual atau biasa disebut media pandang dengar.

Djamarah (2006:124:125) media audio visual adalah media yang mempunyai unsur suara dan unsur gambar. Jenis media ini mempunyai kemampuan yang lebih baik. Media ini dibagi lagi ke dalam: 1) Audio visual Diam, yaitu media yang menampilkan suara dan gambar diam seperti film bingkai suara (sound slides), film rangkai suara, dan cetak suara.

2) Audio visual Gerak, yaitu media yang dapat menampilkan unsur suara dan gambar yang bergerak seperti film suara dan video-cassette.

Video sebenarnya berasal dari bahasa Latin, Video-vidi-visum yang artinya melihat (mempunyai daya penglihatan); Smaldino (2011:374) mengartikannya dengan "The storage of visuals and their display on television-type screen" (penyimpanan/ perekaman gambar dan penanyangannya pada layar televisi). Menurut Sadiman (2007:74) mengatakan bahwa Video sebagai media audio visual yang menampilkan gerak, semakin lama semakin popular dalam masyarakat kita.

Arsyad (2014:50) menyatakan film atau gambar hidup merupakan gambar-gambar dalam frame dimana frame demi frame diproyeksikan melalui lensa proyektor secara mekanis sehingga pada layar terlihat gambar itu hidup. Film bergerak dengan cepat dan bergantian sehingga memberikan visual yang kontinu. Sama halnya dengan film, video dapat menggambarkan suatu objek yang bergerak bersama-sama dengan suara alamiah atau suara yang sesuai. Kemampuan film dan video melukiskan gambar hidup dan suara memberinya daya tarik sendiri. Kedua jenis media ini pada umumnya digunakan untuk tujuan-tujuan hiburan, dokumentasi, dan pendidikan. Mereka dapat menyajikan informasi, memaparkan proses, menjelaskan konsep-konsep yang rumit, mengajarkan keterampilan, menyingkat atau memperpanjang waktu dan mempengaruhi sikap. Sementara menurut Smaldino (2011:7) mengatakan bahwa video merupakan media yang menampilkan gerakan, termasuk DVD, rekaman video, animasi komputer, dan sebagainya.

Kelebihan dan keterbatasan video menurut Sadiman (2003:74-75) adalah sebagai berikut :

1) dapat menarik perhatian untuk periodeperiode yang singkat dari rangsangan luar lainnya
2) dengan alat perekam video sejumlah besar penonton dapat memperoleh informasi dari ahli-ahli/spesialis

3) demonstrasi yang sulit bisa dipersiapkan dan direkam sebelumya sehingga pada waktu mengajar guru memusatkan perhatian pada penyajiannya

4) menghemat waktu dan rekaman dapat dapat diputar berulang-ulang

5) kamera TV bisa mengamati lebih dekat objek yang lagi bergerak atau objek yang lagi bergerak atau objek yang berbahaya seperti harimau;

6) keras lemah suara yang ada bisa diatur dan disesuaikan bila akan disisipi komentar yang akan di dengar

7) gambar proyeksi biasa di-“beku"-kan untuk diamati dengan seksama. Guru bisa mengatur dimana dia akan menghentikan gerakan gambar tersebut; Kontrol sepenuhnya di tangan guru; dan

8) ruangan tak perlu di gelapkan waktu menyajikannya

Sedangkan keuntungan Film dan video menurut Arsyad (2014:50-51) adalah sebagai berikut :

1) Film dan Video dapat melengkapi pengalaman-pengalaman dasar dari siswa ketika mereka membaca, berdiskusi, praktik, dan lain-lain.

2) Film dan Video dapat menggambarkan suatu proses secara tepat yang dapat disaksikan secara berulang-ulang jika dipandang perlu.

3) Disamping mendorong dan meningkatkan motivasi, film dan video menanamkan sikap dan segi-segi afektif lainnya.

4) Film dan video yang mengandung nilainilai positif dapat mengundang pemikiran dan pembahasan dalam kelompok siswa..

5) Film dan video dapat menyajikan peristiwa yang berbahaya bila dilihat secara langsung seperti lahar gunung berapi atau perilaku binatang buas.

6) Film dan video dapat ditunjukkan kepada kelompok besar atau kelompok kecil, kelompok yang heterogen, maupun perorangan.

7) Dengan kemampuan dan teknik pengambilan gambar, frame demi frame, film yang dalam kecepatan normal memakan waktu satu minggu dapat ditampilkan satu atau dua menit.

Video juga bisa dimanfaatkan untuk hampir semua topik, tipe pembelajar, dan setiap 
ranah: kognitif, afektif, psikomotorik, dan interpersonal. Pada ranah kognitif, pembelajar bisa mengobservasi rekreasi dramatis dari kejadian sejarah masa lalu dan rekaman aktual dari peristiwa terkini, karena unsur warna, suara dan gerak di sini mampu membuat karakter berasa lebih hidup. Selain itu menonton video, setelah atau sebelum membaca, dapat memperkuat pemahaman siswa terhadap materi ajar. Lebih dari itu, manfaat dan karakteristik lain dari media video atau film dalam meningkatkan efektifitas dan efesiensi proses pembelajaran, di antaranya adalah (Munadi, 2010:127; Smaldino, 2011: 311-312):

1) Mengatasi jarak dan waktu

2) menggambarkan peristiwa-peristiwa masa lalu secara realistis dalam waktu yang singkat

3) membawa siswa berpetualang dari negara satu ke negara lainnya, dan dari masa yang satu ke masa yang lain.

4) diulang-ulang bila perlu untuk menambah kejelasan

5) Pesan yang disampaikannya cepat dan mudah diingat.

6) Mengembangkan pikiran dan pendapat para siswa

7) Mengembangkan imajinasi

8) Memperjelas hal-hal yang abstrak dan memberikan penjelasan yang lebih realistik

9) berperan sebagai media utama untuk mendokumentasikan realitas sosial yang akan dibedah di dalam kelas

10) berperan sebagai storyteller yang dapat memancing kreativitas peserta didik dalam mengekspresikan gagasannya.

Berikut ini akan dijabarkan kondisi belajar diskriminasi dan psikomotor menurut Gagne (1987) dalam media pembelajaran video: fase motivasi, fase konsentrasi, fase pengolahan, fase menggali, fase umpan balik

\section{Media Pembelajaran Kartu Huruf}

Maimunah Hasan (2009:

mengungkapkan bahwa kartu huruf adalah penggunaan sejumlah kartu sebagai alat bantu untuk belajar membaca dengan cara melihat dan mengingat bentuk huruf dan gambar yang disertai tulisan dari makna gambar pada kartu. Azhar Arsyad (2014:119) mengungkapkan bahwa kartu huruf adalah kartu abjad yang berisi gambar, huruf, tanda simbol, yang meningkatkan atau menuntun anak yang berhubungan dengan simbol-simbol tersebut.
Agus Hariyanto (2009:84) mengungkapkan bahwa media pembelajaran kartu huruf adalah suatu cara dalam kegiatan pembelajaran untuk anak usia dini melalui kartu huruf. Kartu huruf yang digunakan berupa kartu yang terbuat dari karton berbentuk segi empat dan tiap kartu bertuliskan satu huruf kapital dan satu huruf kecil.

Metode yang sering digunakan adalah metode ceramah atau bercakap cakap. Metode bercakap-cakap cenderung hampir digunakan setiap hari di kelas. Metode yang menggunakan percakapan dalam bentuk tanya jawab ini sebaiknya dilakukan dengan banyak arah yaitu tanya jawab antara anak dengan anak, dan antara anak dengan guru. Dengan demikian, bercakap-cakap di sini sudah berkembang menjadi suatu dialog bahkan akan bersifat diskusi karena sudah dapat melibatkan dua orang atau lebih. (Montolalu, dkk: 2009:10.23). Sedangkan Moeslichatoen (2004: 91-92) mengatakan bahwa metode ceramah atau bercakap-cakap merupakan salah satu bentuk komunikasi antarpribadi.

Kelebihan media kartu huruf menurut R. Ibrahim; Nana Syaodih S. (2003:114) adalah sebagai berikut: Mudah di bawa-bawa, Praktis, Gampang diingat, Menyenangkan:

Berikut ini akan dijabarkan kondisi belajar diskriminasi dan konkret menurut Gagne (1987) dalam media pembelajaran kartu huruf :

a) Fase konsentrasi: ciri-ciri disini anak diperkenalkan dengan berbagai huruf melalui media papan flanel.

b) Fase pengolahan: ciri-ciri fisik yang sama diambil bersama-sama. Anak mengamati kembali benda yang ada dihadapkan padanya, untuk menegaskan kembali perbedaan tersebut. Anak menuangkan pengertian benda dalam bentuk kata. Pengolahan ciri-ciri yang khas bagi golongan tertentu, akan ditingkatkan bila ciri-ciri tersebut dibahaskan. Guru menuliskan huruf di papan tulis sesuai huruf dipapan flanel satu huruf dan anak mengikuti di Lembar Kerja (LK).

c) Fase Prestasi: anak membuktikan bahwa dia sudah memiliki konsep yang dipelajari dengan menunjukkan atau memisahmemisahkan disertai dengan penyebutan nama. Anak menuliskan huruf tersebut pada lembar kerja.

d) Fase Umpan Balik: cukup berperan sebagai konfirmasi terhadap penggolongan yang 
telah dibuat. Guru memberikan penguat baik secara lisan maupun tulisan untuk menilai pekerjaan anak.

\section{Hakikat Kreativitas}

Hawadi (2001:3) mengemukakan bahwa kreativitas merupakan suatu bidang kajian yang kompleks, yang menimbulkan berbagai perbedaan pandangan. Perbedaan tersebut terletak pada bagaimana kreativitas itu didefinisikan. Adapun kreativitas didefinisikan, sangat berkaitan dengan penekanan pendefinisian dan tergantung pada dasar teori yang menjadi dasar acuannya. Sementara itu, Jamaris (2006:59) memaparkan bahwa kreativitas merupakan kemampuan seseorang untuk mengendalikan tekanan regresi yang dialaminya. Selain itu, Munandar (1999:28) mengatakan kreativitas adalah kemampuan untuk membuat kombinasi baru, berdasarkan data, informasi, atau unsur-unsur yang ada. Secara operasional kreativitas dapat dirumuskan sebagai kemampuan yang mencerminkan kelancaran, keluwesan dan orisinalitas dalam berpikir serta kemampuan untuk mengelaborasikan (mengembangkan, memperkaya, memperinci suatu gagasan). Definisi pribadi dikemukakan oleh Stenberg (1988) bahwa kreativitas merupakan titik pertemuan yang khas antara tiga atribut psikologis, intelegensi, gaya kognitif dan kepribadian/motivasi. Secara bersamaan ketiga dalam alam pikiran ini membantu memahami apa yang melatarbelakangi individu yang kreatif.

Kreativitas dapat diukur dengan cara mengidentifikasi kemampuan berpikir kreatif yang dimiliki yaitu:

a) Fluency (kelancaran) yaitu kemampuan mengemukakan ide-ide yang serupa untuk memecahkan suatu masalah.

b) Flexibility (keluwesan) yaitu kemampuan untuk menghasilkan berbagai macam ide guna memecahkan suatu masalah di luar kategori yang biasa.

c) Originality (keaslian) yaitu kemampuan memberikan respon yang unik atau luar biasa d) Elaboration (keterperincian) yaitu kemampuan menyatakan pengarahan ide secara terperinci untuk mewujudkan ide tersebut menjadi kenyataan.

Rumusan masalah dalam penelitian ini adalah : (1) Apakah kemampuan menulis huruf anak PAUD yang diajarkan melalui media pembelajaran video lebih tinggi daripada anak PAUD yang diajarkan melalui kartu huruf?; (2) Apakah kemampuan menulis huruf anak PAUD yang memiliki tingkat kreativitas tinggi lebih tinggi daripada anak PAUD yang memiliki tingkat kreativitas rendah?; dan (3) Apakah ada interaksi antara penggunaan media pembelajaran dan kreativitas terhadap kemampuan menulis anak PAUD?

\section{METODE}

Penelitian ini dilaksanakan di PAUD Kenanga Raya. Populasi penelitian ini adalah seluruh anak usia dini yang ada di PAUD Kenanga Raya yang berjumlah 60 orang. Selanjutnya dari populasi penelitian dipilih sampel secara acak (cluster random sampling). Ditentukan kelas A sebagai kelas eksperimen (kelas yang diberi perlakuan dengan menggunaan media pembelajaran video) dengan jumlah sampel 20 orang dan kelas B dengan jumlah sampel 20 orang sebagai kelas kontrol (kelas yang menggunakan media pembelajaran kartu huruf). Jadi seluruh sampel penelitian adalah 40 orang anak.

Penelitian ini menggunakan metode eksperimen dengan rancangan quasi eksperimen desain faktorial $2 \times 2$. Melalui desain ini akan dibandingkan pengaruh media pembelajaran video dan media pembelajaran kartu huruf. Dimana melalui penelitian ini akan dibandingkan pengaruh antara media pembelajaran video dan kartu huruf terhadap kemampuan menulis huruf anak PAUD ditinjau dari tingkat kreativitas tinggi dan kreativitas rendah. Media pembelajaran video dan kartu huruf sebagai variabel bebas, kreativitas tinggi dan kreativitas rendah sebagai variabel moderator dan kemampuan menulis huruf sebagai variabel terikat. Adapun rancangan eksperimen dalam penelitian sebagaimana yang ditunjukkan pada tabel 1. berikut: 
Tabel 1. Rancangan Penelitian Faktorial 2 x 2

\begin{tabular}{|l|c|c|}
\hline Media Pembelajaran (A) & $\begin{array}{c}\text { Media Pembelajaran } \\
\text { Video }\left(\mathbf{A}_{\mathbf{1}}\right)\end{array}$ & $\begin{array}{c}\text { Media Pembelajaran } \\
\text { Kartu Huruf }\left(\mathbf{A}_{\mathbf{2}}\right)\end{array}$ \\
\hline Kreativitas $(\mathbf{B})$ & $\mathrm{A}_{1} \mathrm{~B}_{1}$ & $\mathrm{~A}_{2} \mathrm{~B}_{1}$ \\
\hline Kreativitas Tinggi $\left(\mathrm{B}_{1)}\right.$ & $\mathrm{A}_{1} \mathrm{~B}_{2}$ & $\mathrm{~A}_{2} \mathrm{~B}_{2}$ \\
\hline
\end{tabular}

Keterangan:

$\mathrm{A}=$ Media Pembelajaran

$\mathrm{A}_{1}=$ Media Pembelajaran Video

$\mathrm{A}_{2}=$ Media Pembelajaran Kartu Huruf

$\mathrm{B}=$ Kreativitas

$\mathrm{B}_{1} \quad=$ Kreativitas Tinggi

$\mathrm{B}_{2}=$ Kreativitas Rendah

$\mathrm{A}_{1} \mathrm{~B}_{1}=$ Rata-rata kemampuan menulis huruf anak PAUD yang menggunakan media pembelajaran video dengan kreativitas tinggi

$\mathrm{A}_{2} \mathrm{~B}_{1}=$ Rata-rata kemampuan menulis huruf anak PAUD yang menggunakan media pembelajaran kartu huruf dengan kreativitas tinggi

$\mathrm{A}_{1} \mathrm{~B}_{2}=$ Rata-rata kemampuan menulis huruf anak PAUD yang menggunakan media pembelajaran video dengan kreativitas rendah

$\mathrm{A}_{2} \mathrm{~B}_{2}=$ Rata-rata kemampuan menulis huruf anak PAUD yang menggunakan media pembelajaran kartu huruf dengan kreativitas rendah

Teknik analisis data yang dilakukan dalam penelitian ini adalah teknik analisis varians (ANAVA) pengujian hipotesis dilakukan pada taraf signifikansi $5 \%$. Jika dalam pengujian ANAVA terdapat interaksi penggunaan media pembelajaran dan kreativitas terhadap kemampuan menulis huruf anak PAUD maka dilanjutkan dengan uji lanjut. Jika jumlah sampel tiap sel sama (n sama) maka uji lanjut dilakukan dengan uji Tukey dan jika jumlah sampel pada sel berbeda (n berbeda), maka untuk uji lanjut digunakan uji scheffe. Sebagai uji persyaratan analisis dilakukan pengujian normalitas dengan menggunakan uji liliefors. Setelah uji normalitas dilakukan uji homogenitas dengan menggunakan uji $\mathrm{F}$ dan uji Barlett. Adapun hipotesis yang diuji adalah:

Hipotesis 1: $\quad \mathrm{H}_{0}: \mu \mathrm{A}_{1=} \mu \mathrm{A}_{2}$

$\begin{array}{ll} & H_{a}: \mu A_{1}>\mu A_{2} \\ \text { Hipotesis 2: } & H_{0}: \mu B_{1}=\mu B_{2}\end{array}$

$\mathrm{H}_{\mathrm{a}}: \mu \mathrm{B}_{1}>\mu \mathrm{B}_{2}$

Hipotesis 3: $\quad \mathrm{H}_{0}: \mathrm{A}_{1} \mathrm{x} \mathrm{B}_{2}=0$

dimana :

$$
\mathrm{H}_{\mathrm{a}}: \mathrm{B}_{1} \times \mathrm{B}_{2} \neq 0
$$

$\mu \mathrm{A}_{1} \quad=$ Rata-rata kemampuan menulis huruf anak PAUD yang diajarkan dengan media pembelajaran video.

$\mu \mathrm{A}_{2} \quad=$ Rata-rata kemampuan menulis huruf anak PAUD yang diajarkan dengan media pembelajaran kartu huruf.

$\mu \mathrm{B}_{1} \quad=$ Rata-rata kemampuan menulis huruf anak PAUD yang memiliki kreativitas tinggi.

$\mu \mathrm{B}_{2} \quad=$ Rata-rata kemampuan menulis huruf anak PAUD yang memiliki kreativitas rendah.

$\mathrm{A}_{1} \mathrm{x} \quad \mathrm{B}_{2}=$ Interaksi antara media pembelajaran dengan kreativitas.

$\mathrm{A} \quad=$ Media Pembelajaran

B = Kreativitas

\section{HASIL DAN PEMBAHASAN Hasil Penelitian}

Persyaratan pengujian analisis untuk analysis of varians untuk data tiap kelompok telah dipenuhi, yaitu data setiap kelompok berdistribusi normal, memiliki varians yang homogen dan dari sampel yang ditentukan secara random. Dengan demikian uji hipotesis dengan analysis of varians dua jalur dari Kemampuan menulis huruf dapat dilakukan. Berikut ini akan disajikan pengujian hipotesis penelitian. Hasil analisis data dengan analysis of varians dua jalur dari Kemampuan menulis huruf dapat ditunjukkan dalam Tabel 2. 
Tabel 2. Ringkasan Hasil Analysis of Varians Gabungan

\begin{tabular}{|l|r|r|r|r|r|l|}
\hline \multicolumn{1}{|c|}{$\begin{array}{c}\text { Sumber } \\
\text { Varians }\end{array}$} & \multicolumn{1}{c|}{ JK } & dK & \multicolumn{1}{c|}{ RJK } & \multicolumn{1}{c|}{ Fh } & \multicolumn{1}{c|}{ Ft (a= 0,05) } & Ket \\
\hline Antar Kolom & 2030,62 & 1 & 2030,62 & 378,14 & 4,12 & Signifikan \\
\hline Antar Baris & 238,95 & 1 & 238,95 & 44,5 & 4,12 & Signifikan \\
\hline Interaksi & 485,43 & 1 & 485,43 & 90,4 & 4,12 & Signifikan \\
\hline Galat & 193,4 & 35 & 5,73 & & 4,12 & \\
\hline Total & 2948,4 & 38 & & & & \\
\hline
\end{tabular}

Kemampuan menulis huruf anak PAUD yang diajarkan dengan media pembelajaran video lebih tinggi daripada anak yang diajarkan dengan media pembelajaran kartu huruf Hipotesis statistik yang diuji adalah :

$$
\text { Ho: } \mu_{1}=\mu_{2}
$$$$
\mathrm{Ha}: \mu_{1}>\mu_{2}
$$

Hasil perhitungan menunjukkan nilai $\mathrm{F}_{\text {hitung }}$ sebesar 378,14 sedangkan nilai $\mathrm{F}_{\text {tabel }}$ pada taraf signifikansi 0,05 sebesar 4,12 dengan demikian $\mathrm{F}_{\text {hitung }}>\mathrm{F}_{\text {tabel }}$ pada taraf signifikansi 0,05 . Ini berarti $H_{o}$ ditolak dan $H_{a}$ diterima. Dengan demikian hipotesis penelitian yang menyatakan kemampuan menulis huruf anak yang yang diajarkan dengan media video lebih tinggi daripada anak yang yang diajarkan dengan media kartu huruf teruji kebenarannya.

Kemampuan menulis huruf anak PAUD yang memiliki kreativitas tinggi lebih tinggi daripada anak yang memiliki kreativitas rendah berdasarkan media pembelajaran

Hipotesis statistik yang diuji adalah:

Ho : $\mu_{3}=\mu_{4}$

$\mathrm{Ha}: \mu_{3}>\mu_{4}$

Hasil perhitungan menunjukkan nilai $F_{\text {hitung }}$ sebesar 44,5 sedangkan nilai $F_{\text {tabel }}$ pada taraf signifikansi 0,05 sebesar 4,12 dengan demikian $F_{\text {hitung }}>F_{\text {tabel }}$ pada taraf signifikansi 0,05 . Ini berarti $H_{o}$ ditolak dan $H_{a}$ diterima. Dengan demikian hipotesis penelitian yang menyatakan kemampuan menulis huruf anak yang memiliki kreativitas tinggi lebih tinggi daripada anak yang memiliki kreativitas rendah teruji kebenarannya.

Terdapat pengaruh interaksi antara belajar yang diajarkan dengan media pembelajaran dan kreativitas terhadap Kemampuan menulis huruf

Hipotesis statistik yang diuji adalah:

Ho : $\mathrm{X}_{1} \times \mathrm{X}_{2}=0$

Ha : $X_{1} \times X_{2} \neq 0$

Hasil perhitungan menunjukkan nilai $F_{\text {hitung }}$ sebesar 90,4 sedangkan nilai $F_{\text {tabel }}$ pada taraf signifikansi 0,05 sebesar 4,12 dengan demikian $F_{\text {hitung }}>F_{\text {tabel }}$ pada taraf signifikansi 0,05. Ini berarti $\mathrm{H}_{o}$ ditolak dan $\mathrm{H}_{\mathrm{a}}$ diterima. Dengan demikian hipotesis penelitian yang menyatakan terdapat pengaruh interaksi antara belajar yang diajarkan dengan media pembelajaran dan kreativitas terhadap kemampuan menulis huruf teruji kebenarannya. Adapun interaksi antara pembelajaran dengan kreativitas seperti pada Gambar 1.

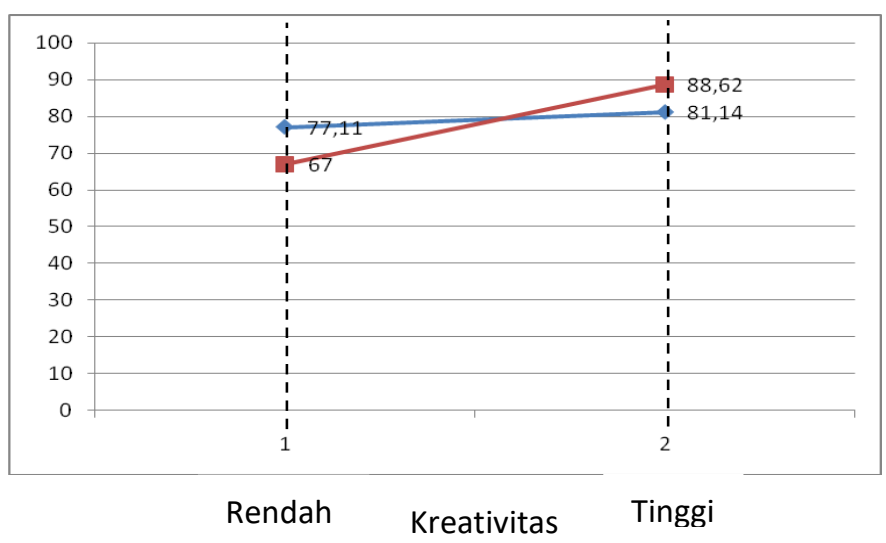

Keterangan Gambar : $\longrightarrow$ Media Pembelajaran Kartu Huruf

Gambar 1. Interaksi Antara Pembelajaran Dengan Kreativitas Terhadap Kemampuan Menulis huruf 
Dari gambar 1 dapat dilihat antara garis belajar yang diajarkan dengan media pembelajaran video membentuk pola interaksi antara menggunakan media pembelajaran kartu huruf. Dari grafik di atas menunjukkan bahwa dalam penelitian ini anak yang memiliki kreativitas tinggi lebih cocok diberikan pembelajaran yang diajarkan dengan media pembelajaran video sedangkan anak yang memiliki kreativitas rendah lebih cocok diberi pembelajaran yang diajarkan dengan media pembelajaran kartu huruf.

Untuk mengetahui interaksi antara kreativitas dalam mempengaruhi kemampuan menulis huruf dilakukan uji lanjut yang diajarkan dengan Uji Scheffe. Ringkasan hasil Uji Scheffe dapat dilihat pada Tabel 3 berikut.

Tabel 3. Ringkasan Hasil Perhitungan Uji Scheffe

\begin{tabular}{|c|c|c|c|c|c|}
\hline No. & \multicolumn{2}{|c|}{ Hasil Uji Lanjut } & $\mathbf{F}_{\text {hitung }}$ & $\mathbf{F}_{\text {tabel }(\mathbf{0}, 05)}$ & Keterangan \\
\hline $\mathbf{1}$ & $\mathrm{F}_{\mathrm{A} 1 \mathrm{~B} 1}$ & $\mathrm{~F}_{\mathrm{A} 1 \mathrm{~B} 2}$ & 6,9 & 3,24 & Signifikan \\
\hline $\mathbf{2}$ & $\mathrm{F}_{\mathrm{A} 2 \mathrm{~B} 1}$ & $\mathrm{~F}_{\mathrm{A} 2 \mathrm{~B} 2}$ & 9,5 & 3,24 & Signifikan \\
\hline $\mathbf{3}$ & $\mathrm{F}_{\mathrm{A} 1 \mathrm{~B} 1}$ & $\mathrm{~F}_{\mathrm{A} 2 \mathrm{~B} 1}$ & 11,4 & 3,24 & Signifikan \\
\hline $\mathbf{4}$ & $\mathrm{F}_{\mathrm{A} 1 \mathrm{~B} 2}$ & $\mathrm{~F}_{\mathrm{A} 2 \mathrm{~B} 2}$ & 12,74 & 3,24 & Signifikan \\
\hline $\mathbf{5}$ & $\mathrm{F}_{\mathrm{A} 1 \mathrm{~B} 1}$ & $\mathrm{~F}_{\mathrm{A} 2 \mathrm{~B} 2}$ & 22,52 & 3,24 & Signifikan \\
\hline $\mathbf{6}$ & $\mathrm{F}_{\mathrm{A} 1 \mathrm{~B} 2}$ & $\mathrm{~F}_{\mathrm{A} 2 \mathrm{~B} 1}$ & 3,47 & 3,24 & Signifikan \\
\hline
\end{tabular}

\section{Pembahasan Hasil Penelitian}

Berkenaan dengan hasil pengujian hipotesis penelitian tersebut, beberapa hal perlu dibahas/didiskusikan lebih lanjut. Pengujian hipotesis menunjukkan bahwa secara keseluruhan kemampuan menulis anak PAUD yang belajar dalam pembelajaran yang diajarkan dengan media pembelajaran video lebih tinggi dari pada kemampuan menulis anak yang belajar dalam pembelajaran yang diajarkan dengan media pembelajaran kartu huruf. Hal ini terjadi karena berbagai hal yang dapat dijelaskan seperti berikut. Pertama, pembelajaran yang diajarkan dengan media pembelajaran video memberikan kesempatan kepada anak untuk dapat melihat dan mengekspresikan pikiran kepada teman sebayanya sehingga kemampuan menulis anak dapat meningkat. Dalam pembelajaran yang diajarkan dengan media pembelajaran kartu huruf anak lebih banyak diberikan kartu huruf secara berulang-ulang sehingga membuat anak bosan. Anak juga sulit mengingat kembali huruf dan cara penulisannya. Kemampuan menulis anak dapat meningkat dengan baik apabila didukung dengan lingkungan yang kaya dengan pembelajaran bahasa. Kedua, pembelajaran yang diajarkan dengan media pembelajaran video memberi tantangan yang cukup besar pada anak untuk melakukan aktivitas belajar sesuai dengan kemampuannya dengan bisa melakonkan orang lain atau diri sendiri berdasarkan pengalaman mainnya.

Untuk anak yang memiliki kreativitas tinggi kemampuan menulisnya lebih tinggi dibanding dengan anak yang memiliki kreativitas rendah. Hal ini terjadi karena beberapa hal. Pertama, anak yang memiliki kreativitas tinggi telah memiliki kepercayaan diri sehingga kesempatan dalam menulis huruf akan memberikan kesempatan pada anak untuk dapat berekspresi mengeluarkan ide-ide atau gagasan yang diimplementasikan dalam bentuk tindakan dengan mencoret-coret atau membentuk garis yang merupakan tahap awal menulis. Sebaliknya anak yang memiliki kreativitas rendah, karena memiliki harga diri yang rendah, kesulitan dalam berekspresi. Kedua, anak yang memiliki kreativitas tinggi menyukai tantangan sehingga dalam kegiatan menulis huruf yang sudah dirancang membuat dia semangat untuk melakukannya bahkan akan bisa berimprovisasi dengan alat dan bahan main yang ada karena ada keyakinan tentang dirinya sendiri, untuk anak yang memiliki kreativitas rendah kurang dapat berimprovisasi karena umumnya hanya menerima saja apa yang diberikan Ibu guru dan kurang ada keyakinan terhadap diri sendiri. Ketiga, anak yang memiliki kreativitas tinggi akan lebih baik apabila diberikan lebih banyak kesempatan menggunakan media pembelajaran video dan untuk anak yang memiliki kreativitas rendah lebih baik diberi lebih banyak kesempatan menggunakan media pembelajaran kartu huruf karena di media pembelajaran video memberi tantangan dan keinginan lebih tinggi daripada media pembelajaran kartu huruf sehingga anak melakukan kegiatan dilandasi oleh keinginan dan kemauannya sendiri, guru hanya tinggal 
memfasilitasi saja. Selanjutnya anak yang memiliki kreativitas rendah perlu terus dimotivasi oleh para guru sehingga semakin memiliki kepercayaan diri yang baik karena kreativitas sebenarnya dapat berubah ke arah yang lebih baik apabila anak mendapat dukungan dari lingkungan sekitarnya sehingga dia berani melakukan dan menyatakan sesuatu yang akhirnya kemampuan menulisnya juga akan bisa lebih meningkat.

Hasil penelitian ini juga mendukung penelitian yang dilakukan Mulia (2012) dan Haezarni (2011) bahwa ada perbedaan hasil belajar yang disebabkan oleh penggunaan media pembelajaran yang tepat sesuai kemampuan anak. Melalui bermain akan mengaktifkan semua kemampuan anak, termasuk kemampuan menulis huruf. Dengan bermain anak tidak merasa terbebani, anak merasa nyaman dan rileks padahal sebenarnya dia sedang belajar. Dengan demikian, pembelajaran yang paling efektif pada anak usia dini adalah dengan bermain.

Temuan penelitian ini juga mendukung penelitian yang dilaksanakan oleh Bangun Sihotang (2012) yang menyimpulkan bahwa penggunaan multimedia sangat mendorong peningkatan hasil belajar siswa dan dapat meningkatkan kemampuan siswa dalam belajar mandiri pada mata pelajaran TUMB. Hasil penelitian menunjukkan bahwa rata-rata hasil belajar TUMB siswa yang memiliki kecerdasan interpersonal

\section{PENUTUP}

Berdasarkan hasil analisis data dan pengujian hipotesis penelitian yang telah dikemukakan, dapat ditarik beberapa simpulan sebagai berikut:

1. Pertama, kemampuan menulis huruf anak PAUD yang mengikuti pembelajaran dengan media pembelajaran video lebih tinggi daripada anak yang mengikuti pembelajaran dengan menggunakan media pembelajaran kartu huruf. Dengan demikian dapat dikatakan bahwa media pembelajaran video lebih efektif digunakan untuk meningkatkan kemampuan menulis huruf anak daripada pembelajaran dengan media pembelajaran kartu huruf.

2. Kedua, anak yang memiliki kreativitas tinggi kemampuan menulis lebih tinggi dibanding dengan anak yang memiliki kreativitas rendah pada kegiatan pembelajaran dengan media pembelajaran video. Dengan demikian untuk meningkatkan kemampuan menulis huruf anak yang memiliki kreativitas tinggi sebaiknya dilakukan melalui pembelajaran dengan media pembelajaran video. Sebaliknya anak yang memiliki kreativitas rendah, skor kemampuan menulis huruf lebih tinggi dibanding dengan anak yang memiliki kreativitas tinggi pada kegiatan pembelajaran dengan media pembelajaran kartu huruf. Dengan demikian dapat dinyatakan bahwa untuk meningkatkan kemampuan menulis anak yang memiliki kreativitas rendah sebaiknya dilakukan melalui pembelajaran dengan media pembelajaran kartu huruf.

3. Ketiga, terdapat pengaruh interaksi antara pembelajaran dengan kreativitas terhadap kemampuan menulis huruf anak PAUD sehingga kreativitas anak perlu terus ditingkatkan oleh guru dengan jalan melatih anak untuk terus kreatif dan terlibat aktif.

Dengan demikian dapat dinyatakan bahwa untuk meningkatkan kemampuan menulis huruf anak PAUD dapat dilakukan melalui pembelajaran dengan menggunakan media pembelajaran, khususnya media pembelajaran video.

\section{DAFTAR PUSTAKA}

Arsyad, Azhar. (2014). Media Pembelajaran. Jakarta: Rajawali Press

Briggs, Leslie J. (1977). Instructional Design, Educational Technology Publications Inc. New Jersey: Englewood Cliffs

Dhieni, Nurbiana. (2011). Metode Pengembangan Bahasa. Jakarta: Universitas Terbuka

Djamarah, Syaiful Bahri. (2002). Psikologi Belajar. Jakarta: Rineka Cipta

Djamarah, Syaiful Bahri. (2006). Strategi Belajar-Mengajar. Jakarta: Rineka Cipta

Gagne, M.R. (1987). The Condition of Learning. USA: Holt, Rine Hart and Wiston

Haezarni, Eben. (2011). "Pengaruh Strategi Pembelajaran dan Kemampuan Berpikir terhadap Hasil Belajar Organ Mahasiswa Jurusan Musik Gerejawi Sekolah Tinggi Agama Kristen Protestan (STAKP) Negeri Tarutung". Jurnal Teknologi Pendidikan Vol. 2 pp.178-186.

Hariyanto, Agus. (2009). Membuat Anak Cepat Pintar Membaca. Jogyakarta: Diva Press 
Hasan, Maimunah. (2009). PAUD (Pendidikan Anak Usia Dini). Jogyakarta: Diva Press

Hasnida. (2015). Media Pembelajaran Kreatif. Jakarta: Luxima

Hawadi, R.A, Wihardjo, R.S.D., dan Wiyono,M. (2001). Kreativitas. Jakarta: Grasindo

Ibrahim, R.; Nana Syaodih S. (2003). Perencanaan Pengajaran. Jakarta: Asdi Mahasatya

Jamaris, Martini. (2006). Perkembangan dan Pengembangan Anak Usia Taman Kanak-kanak. Jakarta: Grasindo

Kasanah, N. \& Tuminto.(2007). Kamus Bergambar. Jakarta

Kunandar. (2007). Guru Profesional; Implementasi Kurikulum Tigkat Satuan Pendidikan dan Sukses Dalam Sertifikasi. Jakarta: Raja Grafindo Persada

Majid, Abdul. (2006). Perencanaan Pembelajaran: Mengembangkan Standar Kompetensi Guru. Bandung: Rosdakarya

Moeslichatoen, R. (2004). Metode Pengajaran di Taman Kanak-kanak. Jakarta: Rineka Cipta

Montolalu, dkk. (2009). Bermain dan Permainan Anak. Jakarta: Universitas Terbuka

Mulia, Eddy. (2012). Pengaruh Media Pembelajaran dan Kemampuan Awal terhadap Hasil Belajar Bahasa Inggris Siswa Sekolah Menengah Pertama Laksamana Martadinata Medan. Tesis. Medan: Pascasarjana Universitas Negeri Medan

Mulyati, dkk. (2011). Seni Menuangkan Gagasan. Jogyakarta: Kanisius

Munadi, Yudi. (2010). Media Pembelajaran: sebuah pendekatan baru. Jakarta: Gaung Persada

National Education Association. 1969. Audiovisual Instruction Department, New
Media And College Teaching.

Washington, D.C.: NEA

Sadiman, Arief S. (2007). Media Pendidikan:

Pengertian, Pengembangan, dan

Pemanfaatannya. Jakarta: RajaGrafindo Persada

Schramm, W. (1977). Big Media Little Media. London: Sage Public-Beverly Hills

Seefeldt, Carol dan Barbara A. Wasik. (2008). Pendidikan Anak Usia Dini. Jakarta: Indeks

Seefeldt, Carol dan Nita Barbour. (1994). Early Childhood Education: An Introduction 3 $r d$ Edition. United State of Amerika: MacMillan Publishing Company

Sihotang, Bangun. (2014). "Penggunaan Multimedia Pembelajaran Dan Kecerdasan Interpersonal Siswa Terhadapa Hasil Belajar Tune Up Motor Bensin”. Jurnal Teknologi Informasi \& Komunikasi dalam Pendidikan Vol. 1 No. 1 Halaman 1-99

Smaldino, Sharon E. (2011). Instructional Technology And Media For Learning: teknologi pembelajaran dan media untuk belajar. Jakarta: Kencana

Sternberg, R. J. 1988. The Nature of Creativity. New York: Cambridge University Press

Sudono. 2000. Sumber Belajar dan Alat Permainan untuk Pendidikan Anak Usia Dini. Jakarta: Gramedia

Sujiono, Yuliani N, dkk. (2010). Bermain Kreatif Berbasis Kecerdasan Jamak. Jakarta: Indeks

Suyadi. (2010). Psikologi Belajar PAUD. Yogyakarta: Pedagogia

Tarigan, Guntur. (1999). Membina Keterampilan Menulis Paragraf dan Pengembangannya. Bandung: Aksara

Yusuf, S. (2000). Psikologi Perkembangan Anak dan Remaja. Bandung: Remaja Rosdakarya 